\title{
SEVENTEEN YEARS OF AMERICAN CUTANEOUS LEISHMANIASIS IN A SOUTHERN BRAZILIAN MUNICIPALITY
}

Wilsandrei CELla(1), Simone Cristina Castanho Sabaini de MELO(2), Cátia Millene DELL AGNOLO(3), Sandra Marisa PELLOSO(4), Thaís Gomes Verzignassi SILVEIRA(5) \& Maria Dalva de Barros CARVALHO(6)

\begin{abstract}
SUMMARY
We reviewed the records of 151 patients diagnosed with American cutaneous leishmaniasis (ACL) from 1993 to 2009 in the municipality of Japura, Paraná, Brazil. Gender, age, occupation, place of residence, location of lesions, type and number of lesions were analyzed. The prevalence rate of ACL was 11.5/10,000 hab, of which $84.7 \%$ were male, 58.3\% lived in rural area and $49.0 \%$ were farmers. The most frequent age group was between 30 to 39 years (26.6\%). Skin lesions occurred in $92.7 \%$ of the patients with predominance in the lower limbs $(23.9 \%)$ and $49.1 \%$ of the records did not include the number of lesions location due to incomplete filling. A single ulceration was present in $44.4 \%$. Japurá is an endemic area for ACL, requiring public actions and preventive education.
\end{abstract}

KEYWORDS: Leishmaniasis; Epidemiology; Zoonoses; Diffuse cutaneous leishmaniasis; Mucocutaneous.

\section{INTRODUCTION}

American Cutaneous leishmaniasis (ACL) is a public health problem in 88 countries across the Americas, Europe, Asia and Africa, with annual incidence of 1-2 million cases ${ }^{2}$. Approximately 14 million people are affected by different forms of leishmaniasis and over 350 million people live in areas at risk ${ }^{22}$.

In Brazil, ACL is widely distributed, with reports in all Brazilian regions ${ }^{4}$, reaching small, medium and large cities since the early twentieth century ${ }^{20}$.

The ACL is a noncontagious infectious disease caused by different species of protozoa of the genus Leishmania, which affects skin and mucous membranes. It is one of dermatological diseases that require more attention due to its magnitude and risk of deformities in the human, its psychological burden reflected in the social and economic field ${ }^{2}$.

Due to the environmental imbalance, insects are acquiring domiciliary habits, increasing the likelihood of human infection. Recent research shows a high density of phlebotomines around the homes ${ }^{17,21}$ which increases the risk of infection in humans and pets, especially dogs ${ }^{12,15,19}$.

ACL prevalence has increased significantly due to factors associated with population migration and insect natural environment as well as the increasing disorganized urbanization in rural areas where occurs the zoonotic cycle $7,10,18,19$. In Brazil, there was an increase in reported cases from 3000 in 1980 to 35748 in 1995 . ACL is endemic in most municipalities of Paraná State, being responsible for $98.7 \%$ of the cases occurred in Southern Brazil ${ }^{1}$.

The geographical distribution of cases of ACL showed a high prevalence in the north and west of Paraná State ${ }^{8}$. Information about the epidemiology is important because it helps in the planning of health actions. With the aim of contributing to increased knowledge about this disease in the state of Paraná, in the present study a survey of the epidemiological characteristics of patients affected by ACL in the period from 1993 to 2009 in the Municipality of Japura, Paraná State, Southern Brazil was carried out.

Our aim was to examine the epidemiologic characteristics of patients affected by ACL in the period from 1993 to 2009 in the Municipality of Japura, Paraná State, Southern Brazil.

\section{MATERIAL AND METHODS}

Methodology: We conducted a cross sectional observational study through analysis of reporting forms from patients with ACL diagnosed between 1993 and 2009 in the municipality of Japura. Data were collected on gender, age, occupation, place of residence, as well as location, type, and number of injuries.

Data were processed statistically using the software Statistic 7.1, adopting a significance level of $5 \%$. 
CELLA, W.; MELO, S.C.C.S; DELL AGNOLO, C.M.; PELLOSO, S.M.; SILVEIRA, T.G.V. \& CARVALHO, M.D.B. - Seventeen years of American cutaneous leishmaniasis in a Southern Brazilian municipality. Rev. Inst. Med. Trop. Sao Paulo, 54(4): 215-8, 2012.

The study was approved by the Ethics and Research Committee of Nursing School at the State University of Northern Paraná - Campus Luiz Meneguel (098/2009).

Characteristics of the area: The municipality of Japura is limited between the coordinates $\left(23^{\circ} 40^{\prime} 10^{\prime \prime}\right.$ south latitude and $52^{\circ} 40^{\prime} 20^{\prime \prime}$ west longitude), its altitude is 555 meters, it is located in the northwest of the Paraná State, in Southern Brazil. The climate of this city is classified as "subtropical". The average temperature in the coldest month is about $18^{\circ} \mathrm{C}$ and mean temperature in the warmest month is about $22^{\circ} \mathrm{C}$, with hot summers, infrequent frosts and a trend towards concentration of rains in the summer months, however with no definite dry season. The vegetation is characterized by semi-deciduous forest formation ${ }^{16}$. The terrain is mainly comprised of plateaus, with only a few wetlands near the rivers. The Japura population is estimated in 9,800 inhabitants, with a total area of $162.08 \mathrm{~km}^{2(16)}$.

\section{RESULTS}

From January 1993 to December 2009, 151 ACL autochthonous cases were reported in the municipality of Japura, with an average annual incidence of $8.8 \%$. During the study period, the municipality had an ACL prevalence of 11.5/10,000 inhabitants (Table 1).

Table 1

Distribution of cases and prevalence of leishmaniasis per year of notification. Japura, Paraná, Brazil, 1993 - 2009

\begin{tabular}{lccc}
\hline Year & Number of cases & Population* & Prevalence** \\
\hline 1993 & 13 & 7529 & 17.2 \\
1994 & 09 & 7589 & 11.8 \\
1995 & 12 & 7642 & 15.7 \\
1996 & 05 & 7698 & 6.4 \\
1997 & 04 & 7603 & 5.2 \\
1998 & 07 & 7533 & 9.2 \\
1999 & 02 & 7457 & 2.6 \\
2000 & 17 & 7755 & 21.9 \\
2001 & 03 & 7705 & 3.8 \\
2002 & 04 & 7683 & 5.2 \\
2003 & 07 & 7644 & 9.1 \\
2004 & 09 & 7610 & 11.8 \\
2005 & 05 & 7529 & 6.6 \\
2006 & 15 & 7492 & 20.0 \\
2007 & 13 & 7456 & 17.4 \\
2008 & 14 & 8585 & 16.3 \\
2009 & 12 & 8661 & 13.9 \\
\hline Total & $\mathbf{1 5 1}$ & $\mathbf{1 3 1 1 7 1}$ & $\mathbf{1 1 . 5}$ \\
\hline
\end{tabular}

*Data obtained DATASUS, 2011. **10,000/inhabitants.

The average age of the 151 patients was $35.79 \pm 16.55$ years, ranging from one to 79 years, and most of them were male $(84.7 \%)$. The most frequent professional activity was rural worker $(49.0 \%)$ and $58.3 \%$ of the patients lived in rural areas.
The most frequent age range was 30-39 (26.6\%), followed by 20-29 (21.8\%) and 40-49 (17.2\%). Together, patients between 20-49 years were responsible for $65.6 \%$ of the cases (Table 2).

Table 2

Patients affected by ACL by variables: gender, age range, occupation and place of residence in the municipality of Japura, Paraná, Brazil, in the period 1993 to 2009

\begin{tabular}{lcc}
\hline Features & n. & $\%$ \\
\hline Gender & & \\
Male & 128 & 84.7 \\
Female & 23 & 15.3 \\
Age range & & \\
$0-9$ & 05 & 3.3 \\
$10-19$ & 16 & 10.6 \\
$20-29$ & 33 & 21.8 \\
$30-39$ & 40 & 26.6 \\
$40-49$ & 26 & 17.2 \\
$50-59$ & 11 & 7.3 \\
60 or more & 18 & 11.9 \\
No information & 02 & 1.3 \\
Occupation & & \\
Rural worker & 74 & 49.0 \\
Student & 09 & 6.0 \\
Housework & 12 & 7.9 \\
Other occupations & 47 & 31.1 \\
No information & 09 & 6.0 \\
Place of residence & & 58.3 \\
Rural area & 88 & 41.7 \\
Urban area & 63 & \\
\hline
\end{tabular}

Patients with ACL were diagnosed based on clinical and laboratory findings. Skin lesions were present in $92.7 \%$ of the patients, mainly in the lower limbs (23.9\%) with a single ulcer in $44.4 \%$ (Table 3). Of the 151 patients treated, in $49.1 \%(n=74)$ it was not possible to obtain information on the location of the lesion and in $49.7 \%(n=75)$ we were not able to find the number of injuries in the forms.

\section{DISCUSSION}

The lowest prevalence of ACL in the municipality of Japura was from 1996 to 1999 and from 2001 to 2005 . The highest prevalences were recorded in 1993, 2000 and 2006 (seven and six years apart, respectively), suggesting a cyclical behavior of the disease, already corroborating what is shown in other studies ${ }^{18}$.

During the 17 years covered by this investigation, males accounted for $84.7 \%$ of the cases. Similar rates were reported by LIMA et al. ${ }^{9}$ in 11 municipalities in the northwestern of Paraná State. A retrospective study in the University of Maringa (Paraná State) from 1987 to 2004, found 1611 ACL cases in Paraná, with $73.2 \%$ of the cases in males ${ }^{13}$. However, in a study involving 140 individuals in Rio Grande do Norte State, Northeast Brazil, females represented $57.9 \%$ of the cases ${ }^{15}$. 
Table 3

Patients affected by ACL according to clinical form, location and number of lesions in the municipality of Japura, Paraná, Brazil, in the period from 1993 to 2009

\begin{tabular}{lcc}
\hline Features & $\mathrm{n}$ & $\%$ \\
\hline Clinical Form & 6 & \\
Mucosal & 140 & 4.0 \\
Cutaneous & 3 & 92.7 \\
Mucosal/cutaneous & 2 & 2.0 \\
$\quad$ No information & 1.3 \\
Lesion location & 14 & \\
Upper limbs & 36 & 9.2 \\
Lower limbs & 17 & 23.9 \\
Head & 4 & 11.3 \\
Trunck & 4 & 2.6 \\
Upper and lower limbs & 2.6 \\
Upper, lower and other locations & 2 & 1.3 \\
No information & 74 & 49.1 \\
Number of lesions & & \\
One & 67 & 44.4 \\
Two & 8 & 5.3 \\
Three or more & 1 & 0.6 \\
No information & 75 & 49.7 \\
\hline
\end{tabular}

In another study conducted between 1986 and 2006 in Paraná State, of 2660 patients with ACL, $1656(62.31 \%)$ had skin or mucous membrane lesions. Of these, $97.9 \%$ acquired the infection in the Paraná State, and most were male $(72.6 \%)^{6}$.

Regarding the occupation, $49.0 \%$ of subjects were rural workers. Similar data were found by MARTINS et al. ${ }^{11}$ in Maranhão. This author found a relationship between occupation and gender as well as occupation and place of residence, showing that men who work or live in rural areas are more vulnerable to the disease.

The occupations related to the agricultural activity represented the majority of the cases of leishmaniasis in Paraná State, according to data from MONTEIRO et al. ${ }^{13}$. In his study, 648 (40.8\%) subjects lived in rural areas and $940(59.2 \%)$ in urban ${ }^{13}$.

ACL occurs in both sexes and all age ranges, however it occurs mostly after 10 years of age ( $90 \%$ of cases) $)^{3}$. In Japura, the age range from 20 to 49 years represents $47.9 \%$ of the total population and $65.6 \%$ of the ACL cases (most prevalent age group). These data are relevant according to CHAGAS et al. ${ }^{5}$ in the Amazon region, LIMA et al. ${ }^{8}$ in Paraná State and MARTINS et al. ${ }^{11}$ in Maranhão State, where the most affected age group was 21 and 50 years. This age range and gender distribution coincides with both the most productive time of life and male predominance of agricultural work. Such factors are associated with increased exposure to vectors during daily activities. The age range of highest ACL prevalence among the cases studied in Paraná State was 30 to 49 years $^{6}$.

The majority of the ACL patients $(62.4 \%)$ of our study lived in rural area. Data from Paraná between the years 1987 to 2004, showed that $1493(92.7 \%)$ individuals were infected in rural areas and only 118 $(7.3 \%)$ in urban area ${ }^{14}$.

The predominant clinical presentation was cutaneous $(92.7 \%)$, in agreement with data found in other study done in Paraná State ${ }^{6}$. Among our patients, a single lesion was found in $44.4 \%$. Similar data were found in the literature by other authors ${ }^{15}$. Most patients had lesions in the lower limbs (23.9\% of cases) confirming the findings of OLIVEIRA et $a l .{ }^{15}$ and CASTRO et al. ${ }^{4}$, where $65.0 \%$ and $47.7 \%$ respectively of the lesions were in the lower limbs. It is noteworthy that no information was found regarding the number of lesions in $49.7 \%$ and its location in $49.1 \%$ of the patients.

Recent studies show that after the decentralization of the Brazilian National Health System to the Basic Health Units, epidemiological data is still incomplete and there was no reduction of ACL cases, showing that there was no improvement of the quality of patient care ${ }^{9}$.

\section{CONCLUSION}

Leishmaniasis is endemic in Japura. It affects mainly male rural workers. The cutaneous form was more frequent, and most patients had only one lesion.

The increased number of urban cases in our study compared with others shows a current trend of vector adaptation to new reservoirs in urban buildings, making its control more difficult.

These results indicate the need to increased surveillance, prevention, and more adequate monitoring of suspected and confirmed cases, as well as more efficient vector control.

Our study has several limitations. It was retrospective, undernotification cannot be excluded and most reported forms were incomplete.

\section{RESUMO}

\section{Dezessete anos de leishmaniose tegumentar americana em um município do Sul do Brasil}

Foram revistos os registros de 151 pacientes diagnosticados com leishmaniose tegumentar americana (LTA) de 1993-2009 no município de Japurá, Paraná, Brasil. Sexo, idade, profissão, local de residência, localização das lesões, tipo e número de lesões foram analisadas. A taxa de prevalência de LTA foi 11,5/10.000 hab, dos quais 84,7\% eram do sexo masculino, 58,3\% viviam na área rural e 49,0\% eram agricultores. A faixa etária mais freqüente foi entre 30 a 39 anos (26,6\%). Lesões de pele ocorreram em $92,7 \%$ dos pacientes com predominância nos membros inferiores $(23,9 \%)$ e 49,1\% dos registros não incluem o número e localização de lesões devido ao preenchimento incompleto. Ulceração única estava presente em 44,4\%. Japurá é uma área endêmica para LTA, exigindo ações públicas e educação preventiva.

\section{REFERENCES}

1. Brasil. Ministério da Saúde. Manual de controle da leishmaniose tegumentar americana. Brasília: Fundação Nacional de Saúde; 2006. 
2. Brasil. Ministério da Saúde. Secretaria de Vigilância em Saúde. Manual de vigilância da leishmaniose tegumentar americana. 2. ed. atualizada. Brasília: Editora do Ministério da Saúde; 2010. (Serie A. Normas e Manuais Técnicos).

3. Brasil. Ministério da Saúde. Secretaria de Vigilância em Saúde. Manual de vigilância da leishmaniose tegumentar americana. 2. ed. atualizada. Brasília: Editora do Ministério da Saúde, 2007. (Serie A. Normas e Manuais Técnicos).

4. Castro EA, Soccol VT, Membrive N, Luz E. Estudo das características epidemiológicas e clínicas de 332 casos de leishmaniose tegumentar notificados na região norte do Estado do Paraná de 1993 a 1998. Rev Soc Bras Med Trop. 2002;35:445-52.

5. Chagas AC, Pessoa FAC, Medeiros JF de, Py-Daniel V, Mesquita EC, Balestrassi DA. Leishmaniose tegumentar americana (LTA) em uma vila de exploração de minérios Pitinga, município de Presidente Figueiredo, Amazonas, Brasil. Rev Bras Epidemiol. 2006;9:186-92

6. Curti MCM, Silveira TGV, Arraes SMAA, Bertolini DA, Zanzarini PD, Venazzi EAS, et al. Aspectos epidemiológicos da leishmaniose tegumentar americana na Região Noroeste do Estado do Paraná. Rev Ciênc Farm Básica Apl. 2009;30:63-8.

7. Dias ES, França-Silva JC, Silva JC da, Monteiro EM, Paula KM de, Gonçalves CM, et al. Flebotomíneos (Diptera: Psychodidae) de um foco de leishmaniose tegumentar no Estado de Minas Gerais. Rev Soc Bras Med Trop. 2007;40:49-52.

8. Lima AP, Minelli L, Comunello E, Teodoro U. Distribuição da leishmaniose tegumentar por imagens de sensoriamento remoto orbital, no estado do Paraná, Sul do Brasil. An Bras Dermatol. 2002;77:681-92.

9. Lima MVN, Oliveira RZ, Lima AP, Felix ML, Silveira TGC, Rossi RM, et al. Atendimentos dos pacientes com leishmaniose tegumentar americana: avaliação dos serviços de saúde de municípios do noroeste do estado do Paraná, Brasil. Cad Saúde Pública. 2007;23:2938-48

10. Lonardoni MCV, Silveira TGV, Alves WA, Maia-Elkhoury ANS, Membrive UA, Membrive NA, et al. Leishmaniose tegumentar americana humana e canina no município de Mariluz, Estado do Paraná, Brasil. Cad Saúde Pública. 2006;22:2713-6.

11. Martins LM, Rebêlo JMM, dos Santos MCFV, Costa JML, da Silva AR, Ferreira L. Ecoepidemiologia da leishmaniose tegumentar no Município de Buriticupu, Amazônia do Maranhão, Brasil, 1996 a 1998. Cad Saúde Pública. 2004;20:735-43.

12. Massafera R, da Silva AM, Carvalho AP, dos Santos DR, Galati EAB, Teodoro U. Fauna de flebotomíneos do Município de Bandeirantes, no Estado do Paraná. Rev Saúde Pública. 2005;39:571-7.
13. Monteiro WM, Neitzke-Abreu HC, Ferreira MEMC, Melo GC, Barbosa MGV, Lonardoni MVC, et al. Mobilidade populacional e produção da leishmaniose tegumentar americana no Estado do Paraná, sul do Brasil. Rev Soc Bras Med Trop. 2009;42:509-14.

14. Monteiro WM, Neitzke-Abreu HC, Silveira TGV, Lonardoni MVC, Teodoro U, Ferreira MEMC. Pólos de produção de leishmaniose tegumentar americana no norte do Estado do Paraná, Brasil. Cad Saúde Pública. 2009;25:1083-92.

15. Oliveira CCG; Lacerda HG, Martins DR, Barbosa JDA, Monteiro GR, Queiroz JW, et al. Changing epidemiology of American cutaneous leishmaniasis (ACL) in Brazil: a disease of the urban - rural interface. Acta Trop. 2004;90:155-62.

16. Plano Diretor de uso e ocupação do solo urbano - Japurá - Paraná, 2005. v. único, p. 14-22.

17. Resende MC, Camargo MCV, Vieira JRM, Nobi RCA, Porto NMN, Oliveira L de, et al. Variação sazonal de Lutzomyia longipalpis em Belo Horizonte, Estado de Minas Gerais. Rev Soc Bras Med Trop. 2006;39:51-5.

18. Secretaria de Estado da Saude de São Paulo. Superintendência de Controle de Endemias (Sucen), Taubaté. Aspectos epidemiológicos da leishmaniose tegumentar americana no município de Ubatuba, litoral de São Paulo, Brasil, 1993-2003. Rev Saúde Pública. 2004;38:331-2.

19. Silva DF, Freitas RA, Franco AMR. Diversidade e abundância de flebotomíneos do gênero Lutzomyia (Diptera: Psychodidae) em áreas de mata do nordeste de Manacapuru, AM. Neotrop Entomol. 2007;36:138-44.

20. Teodoro U, Alberton D, Kuhl JB, dos Santos ES, dos Santos DR, dos Santos AR, et al. Ecologia de Lutzomyia (Nyssomyia) whitmani em área urbana do município de Maringá, Paraná. Rev Saúde Pública. 2003;37:651-6.

21. Teodoro U, dos Santos DR, dos Santos AR, Oliveira O, Poiani LP, da Silva AM, et al. Informações preliminares sobre Flebotomíneos do Norte do Paraná. Rev Saúde Pública. 2006;40:327-30

22. World Health Organization. Control of Leishmaniasis. Executive Board. $118^{\text {th }}$ session, 2006. p. 1-7. Cited: 2011, Sept 26. Available from: http://apps.who.int/gb/ebwha/ pdf_files/EB118/B118_4-en.pdf

Received: 27 September 2011

Accepted: 27 April 2012 